\title{
Kebijakan Peningkatan Usaha Mikro, Kecil, dan Menengah di Indonesia
}

\author{
Ade Irvi Nurul Husna \\ STAI DR. KHEZ. Muttaqien Purwakarta, Indonesia \\ ade.irvi.nurul@gmail.com
}

Kata kunci:
Kebijakan
UMKM
Wirausaha

\begin{abstract}
ABSTRAK
Indonesia merupakan suatu negara yang memiliki beragam potensi untuk menjadi negara dengan ekonomi skala besar. Indonesia memiliki potensi pada sumber daya alam dan manusia, serta iklim investasi yang kondusif. Namun Indonesia juga masih memiliki berbagai permasalahan seperti pengangguran dan kemiskinan. Kehadiran UMKM memiliki peran penting dalam perekonomian Indonesia. Penyerapan tenaga kerja dan peningkatan pendapatan salah satu permasalahan yang dapat diatasi dengan hadirnya UMKM. Ketika terjadi kondisi krisis ekonomi maka sektor ekonomi khususnya UMKM yang mampu bertahan. Pemerintah perlu menetapkan kebijakan yang bertujuan untuk meningkatkan kemampuan UMKM baik secara kuantitas maupun kualitas. Peningkatan UMKM juga perlu adanya dukungan dari masyarakat dengan menumbuhkan jiwa wirausaha. Tujuan dari penelitian ini adalah untuk mengkaji kebijakan dalam upaya peningkatan usaha mikro, kecil, dan menengah di Indonesia sebagai salah satu penanganan dalam masalah pengangguran dan kemiskinan. Jenis penelitian yang digunakan yaitu penelitian kepustakaan (library research). Penelitian ini menggunakan metode dengan pendekatan kualitatif yang menyajikan analisa bersifat deskriptif. Fokus peningkatan kegiatan pelaku UMKM ditujukan kepada masyarakat berpenghasilan rendah, wirausahawan, pengangguran, dan investor. Aspek kebijakan pada UMKM terdiri atas 8 aspek yaitu pendanaa, sarana dan prasarana, informasi usaha, kemitraan, perizinan usaha, kesempatan berusaha, promosi dagang, dan dukungan kelembagaan.
\end{abstract}

\section{A. Pendahuluan}

Copyright (O) 2020 (Ade Irvi Nurul Husna). DOI: https://doi.org/10.52593/mtq.01.1.03 Naskah diterima: 19 September 2019, direvisi: 4 Maret 2020, disetujui: 27 Juni 2020

Usaha mikro lebih mendominasi dari sisi jumlah dibandingkan usaha kecil, yaitu mencapai 90 persen. UMK khususnya usaha mikro mempunyai ciri jika tempat usahanya tidak selalu menetap, sewaktuwaktu dapat berpindah tempat. Jenis barang/ komoditi pun tidak selalu tetap, sewaktu-waktu dapat berganti (Bank Indonesia, 2014).

Berdasar Undang-Undang Nomor 20 Tahun 2008 Tentang Usaha Mikro, Kecil dan Menengah (UU UMKM) Pasal 1 dan Pasal 6 ayat (1), (2), dan (3) memberikan kriteria bagi UMKM yang digolongkan berdasarkan jumlah aset dan omset yang dimiliki sebuah usaha yaitu sebagai berikut:

1. Usaha Mikro adalah usaha produktif milik orang perorangan dan/atau badan usaha perorangan yang memenuhi kriteria. Kriteria Usaha Mikro adalah sebagai berikut:

a. memiliki kekayaan bersih paling banyak Rp50.000.000,00 (lima puluh juta rupiah) tidak termasuk tanah dan bangunan tempat usaha; atau

b. memiliki hasil penjualan tahunan paling banyak Rp300.000.000,00 (tiga ratus juta rupiah). 
2. Usaha Kecil adalah usaha ekonomi produktif yang berdiri sendiri, yang dilakukan oleh orang perorangan atau badan usaha yang bukan merupakan anak perusahaan atau bukan cabang perusahaan yang dimiliki, dikuasai, atau menjadi bagian baik langsung maupun tidak langsung dari Usaha Menengah atau Usaha Besar yang memenuhi kriteria. Kriteria Usaha Kecil adalah sebagai berikut:

a. memiliki kekayaan bersih lebih dari Rp50.000.000,00 (lima puluh juta rupiah) sampai dengan paling banyak Rp500.000.000,00 (lima ratus juta rupiah) tidak termasuk tanah dan bangunan tempat usaha; atau

b. memiliki hasil penjualan tahunan lebih dari Rp300.000.000,00 (tiga ratus juta rupiah) sampai dengan paling banyak Rp2.500.000.000,00 (dua milyar lima ratus juta rupiah)

3. Usaha Menengah adalah usaha ekonomi produktif yang berdiri sendiri, yang dilakukan oleh orang perorangan atau badan usaha yang bukan merupakan anak perusahaan atau cabang perusahaan yang dimiliki, dikuasai, atau menjadi bagian baik langsung maupun tidak langsung dengan Usaha Kecil atau Usaha Besar dengan jumlah kekayaan bersih atau hasil penjualan tahunan sebagaimana diatur dalam UndangUndang ini. Kriteria Usaha Menengah adalah sebagai berikut:

a. memiliki kekayaan bersih lebih dari Rp500.000.000,00 (lima ratus juta rupiah) sampai dengan paling banyak Rp10.000.000.000,00 (sepuluh milyar rupiah) tidak termasuk tanah dan bangunan tempat usaha; atau

b. memiliki hasil penjualan tahunan lebih dari Rp2.500.000.000,00 (dua milyar lima ratus juta rupiah) sampai dengan paling banyak Rp50.000.000.000,00 (lima puluh milyar rupiah).

Usaha kecil umumnya adalah usaha yang mempekerjakan karyawan kurang dari 50 karyawan, sementara usaha mikro adalah usaha yang mempekerjakan karyawan paling banyak 10 orang. Hasil Sensus Ekonomi Tahun 2016 Lanjutan atau dikenal SE2016Lanjutan menyatakan bahwa jumlah Usaha Mikro Kecil mencapai lebih dari 26 juta usaha atau 98,68 persen dari total usaha nonpertanian di Indonesia. Usaha ini juga mampu menyerap tenaga kerja lebih dari 59 juta orang atau sekitar 75,33 persen dari total tenaga kerja nonpertanian.

Mayoritas UMK di Indonesia beroperasi secara komersil dalam waktu yang relatif tidak lama, yaitu kurang dari 10 tahun. Keberhasilan usaha dapat ditentukan oleh lama waktu beroperasi (lamanya usaha memproduksi barang maupun jasa). Usaha/perusahaan yang telah lama berdiri biasanya mempunyai strategi yang lebih solid untuk tetap bisa bertahan dalam melakukan aktivitas ekonominya. Semakin lama sebuah perusahaan berdiri, dapat diasumsikan memiliki pengalaman yang beragam baik dalam hal kemajuan maupun kendala yang dihadapi. Namun baru sekitar seperempat UMK di Indonesia yang beroperasi secara komersial lebih dari 15 tahun (BPS, 2019).

Menurut CIDES (Center for Information and Development Studies) terdapat beberapa keunggulan UMK (Meryana, 2012), diantaranya:

1. menghasilkan barang konsumsi dan jasa yang dekat dengan kebutuhan masyarakat 
2. tidak mengandalkan bahan baku impor dan lebih memanfaatkan sumber daya lokal baik dari sisi sumber daya manusia, modal, bahan baku, maupun peralatannya

3. menggunakan modal sendiri atau tidak ditopang pinjaman dari bank.

Pengaruh krisis ekonomi tidak dirasakan UMK lebih jauh dibandingkan UMB (Usaha Menengah Besar) karena minimnya interaksi dengan mata uang asing (BPS, 2019). Penyerapan tenaga kerja di luar Sektor Pertanian di Indonesia mencapai lebih dari 75 persen. UMK banyak yang didirikan oleh individu atau rumah tangga miskin karena tidak mendapatkan kesempatan kerja yang lebih baik. Pengembangan UMK merupakan salah satu solusi terbaik untuk mengurangi pengangguran sekaligus mengurangi kemiskinan (Tambunan, 2012). Beberapa keterbatasan UMK menurut LPPI dan BI (2015) di antaranya:

1. minimnya akses perbankan;

2. kemampuan dan pengetahuan SDM yang masih rendah sehingga dikelola dengan cara yang sederhana;

3. penggunaan teknologi yang terbatas;

4. belum mampu mengimbangi perubahan selera konsumen khususnya yang berorientasi ekspor.

Menurut Yuli (2017) beberapa kelemahan UMKM diantaranya:

1. kurangnya permodalan baik jumlah maupun sumbernya

2. kurangnya kemampuan manajerial dan keterampilan beroperasi dalam mengorganisir

3. terbatasnya pemasaran

4. persaingan yang kurang sehat

5. desakan ekonomi sehingga mengakibatkan ruang lingkup usaha menjadi sempit dan terbatas

Hasil penelitian Kementerian Koperasi dan Usaha Mikro Kecil dan Menengah yang bekerjasama dengan BPS (Sulaeman, 2004), beberapa permasalahan yang dihadapi UMKM umumnya meliputi:

1. kesulitan permodalan (51,09 persen),

2. pemasaran ( 34,72 persen),

3. bahan baku (8,59 persen),

4. ketenagakerjaan (1,09 persen),

5. distribusi transportasi $(0,22$ persen $)$ dan

6. lainnya (3,93 persen).

UMK mempunyai peran yang penting khususnya pada usaha-usaha yang memanfaatkan sumber daya alam maupun padat tenaga kerja. Usaha tersebut umumnya tercakup pada Sektor Pertanian, Peternakan, Kehutanan, dan Perikanan, serta Sektor Perdagangan, Hotel, dan Restoran (BPS, 2019). Bila UMKM diberikan keleluasaan dari 
beberapa aspek diharapkan mampu mengalami peningkatan baik dari segi kualitas maupun kuantitas.

Berdasar latar belakang tersebut maka peneliti tertarik untuk melakukan penelitian kepustakaan mengenai kebijakan peningkatan usaha mikro, kecil, dan menengah di Indonesia.

Berdasarkan fokus penelitian di atas, maka rumusan masalah dalam penelitian ini yaitu bagaimana kebijakan peningkatan pelaku usaha mikro, kecil, dan menengah?. Penelitian ini bertujuan untuk mendeskripsikan kebijakan peningkatan pelaku usaha mikro, kecil, dan menengah.

Manfaat kajian studi pustaka ini yaitu diharapkan dapat memberikan sumbangan pemikiran bagi pengembangan ilmu pengetahuan khususnya pada bidang studi ekonomi dan bisnis serta sebagai acuan pemerintah dalam mengambil kebijakan UMKM. Hasil penelitian ini diharapkan menjadi masukan kepada masyarakat secara umum dalam memahami kebijakan pemerintah dalam upaya peningkatan usaha mikro, kecil, dan menengah di Indonesia.

\section{B. Teori / Konsep}

\section{UMKM Penggerak Pertumbuhan Ekonomi}

Peran UMK dalam kegiatan ekonomi lokal semakin kuat, lapangan pekerjaan pun makin meningkat. Peran dalam penyerapan tenaga kerja mencapai lebih dari 75 persen tenaga kerja di luar Sektor Pertanian di Indonesia (BPS, 2019). Sektor Pertanian, Peternakan, Kehutanan, dan Perikanan, serta Sektor Perdagangan, Hotel, dan Restoran memberikan sumbangan dari kedua sektor ini dalam nilai tambah UMK sebesar 77,68 persen (LPPI dan BI, 2015). UMK mengurangi pengangguran dan menciptakan nilai tambah dalam PDB.

Di setiap wilayah di Indonesia UMK menjadi kekuatan tersendiri dalam pergerakan perekonomian regional. Hal ini terlihat dari dominasi jumlah aktivitas/ usahanya, hampir di setiap wilayah persentasenya lebih dari 98 persen (BPS, 2019). Pertumbuhan PDB UMK selalu meningkat dapat mengindikasikan peningkatan kinerja UMK. Peningkatan ini diharapkan mampu meningkatkan pendapatan penduduk pada level menengah ke bawah sebagai pelaku UMK.

Laporan dari McKinsey Global Institute memprediksikan bahwa Indonesia akan menjadi negara peringkat ke-7 ekonomi terbesar di dunia pada tahun 2030 nanti (Prasetyanoko, 2019). Dengan market opportunity pada sektor jasa, pertanian dan perikanan, sumber daya alam, serta pendidikan.

Kekuatan ekonomi besar yang didukung oleh potensi ekonomi yang dimiliki oleh Indonesia ini bersumber dari:

a) sumber daya alam, terutama pada sektor pertanian/ kelautan, kehutanan, dan pertambangan. Pada sektor pertanian, Indonesia merupakan salah satu dari tiga negara penghasil karet di dunia, negara terbesar ketiga penghasil kopi, dan salah satu penghasil utama dunia untuk kelapa, tembakau, kakao, dan rempah-rempah. Sementara itu, mengingat dua per tiga wilayah Indonesia berupa laut, Indonesia 
memiliki cadangan ikan yang sangat kaya. Hutan di Indonesia merupakan hutan terbesar ketiga di dunia, sehingga memiliki kekayaan hutan yang melimpah. Untuk sektor pertambangan, Indonesia kaya akan cadangan mineral seperti timah, tembaga, emas, bauksit dan nikel. Indonesia juga dikenal sebagai eksportir terbesar gas alam cair

b) sumber daya manusia, Indonesia memiliki jumlah penduduk terbesar di dunia, diperkirakan jumlah penduduk Indonesia tahun 2017 mencapai lebih dari 260 juta penduduk. Pada tahun 2020 sampai 2030, Indonesia akan mendapatkan bonus demografi, dimana jumlah penduduk usia angkatan kerja (15-64 tahun) akan mencapai 70 persen

c) stabilitas makroekonomi, dari tahun ke tahun menunjukkan kondisi yang relatif stabil di tengah kondisi ekonomi global yang mengalami kelesuan. Pertumbuhan ekonomi Indonesia terus berada dalam tren yang positif dan berada di atas pertumbuhan ekonomi global. Tahun 2010 pertumbuhan ekonomi mencapai 6,1 persen dan sampai tahun 2016 pertumbuhan ekonomi tetap terjaga positif di level 5,02 persen. Level inflasi Indonesia juga terjaga di bawah 10 persen selama beberapa tahun terakhir. Tahun 2016, inflasi Indonesia hanya berada di level 3 persen (Sony, 2017).

\section{Pelaku UMKM di Indonesia}

Pelaku UMK paling banyak berusaha pada Sektor Perdagangan Besar dan Eceran, Reparasi dan Perawatan Mobil dan Sepeda Motor (Kategori G). Jumlah usaha pada sektor ini mendominasi jumlah UMK dengan jumlah mencapai hampir 50 persen. Usaha Penyediaan Akomodasi dan Penyediaan Makan Minum (Kategori I) dan Industri Pengolahan (Kategori C) juga mempunyai kontribusi yang besar, dengan kontribusi masing-masing lebih dari 16 persen.

Kualitas pendidikan pengelola UMK masih rendah. Hasil Sensus Ekonomi 2016 Lanjutan menyatakan bahwa terdapat lebih dari 40 persen pengelola berpendidikan SD atau tidak tamat SD. Pengelola dengan pendidikan SMA dan SMK juga cukup besar mencapai 30 persen. Pengangguran banyak terjadi pada lulusan SMA yang berjumlah sekitar 8 persen. Hal ini mengindikasikan bahwa pengangguran cukup banyak terjadi pada angkatan kerja dengan tingkat pendidikan menengah. Pembekalan keterampilan bagi angkatan kerja dengan tingkat pendidikan ini ini akan menjadi aksi yang sangat strategis agar mereka mampu menciptakan usaha sendiri. UMK merupakan salah satu wadah yang paling tepat untuk menampung para tenaga kerja yang tidak memiliki skill tinggi (BPS, 2019). 


\section{Jumlah UMK menurut Kategori}

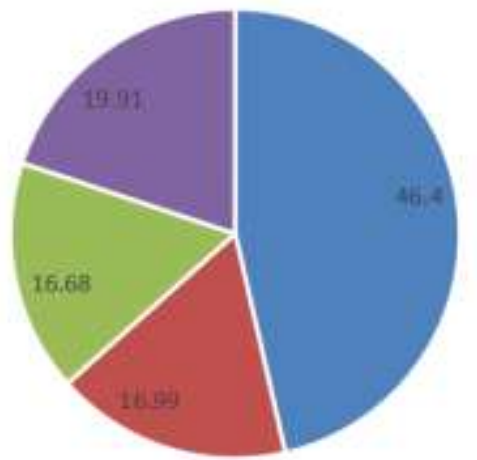

- Kategori G a Kategori I = Kategori C $=$ Kategori Lainnya

Sumber: BPS, 2019 (data diolah kembali)

Usaha sebagian besar digerakkan oleh penduduk kelas menengah ke bawah, sebaran jumlah UMK juga mengikuti sebaran jumlah penduduk. Pulau Jawa dengan jumlah penduduk hampir setengah penduduk Indonesia masih menjadi konsentrasi UMK. Jumlah UMK di pulau ini mencapai lebih dari 60 persen. Provinsi Jawa Timur, Jawa Barat, dan Jawa Tengah merupakan tiga provinsi dengan jumlah UMK tertinggi di Indonesia. Sementara provinsi lain di luar Jawa dengan jumlah UMK yang besar adalah Sumatera Utara dan Sulawesi Selatan (BPS, 2019).

Berdasar Sensus Ekonomi 2016 Lanjutan, jumlah UMK yang tidak berbadan usaha masih sangat mendominasi yaitu mencapai lebih dari 90 persen. Mayoritas UMK juga belum menggunakan komputer dan memanfaatkan internet. Kurang dari 10 persen UMK yang menggunakan komputer dan memanfaatkan internet.

Menurut Undang-Undang RI Nomor 20 Tahun 2008, Usaha Mikro, Kecil, dan Menengah berasaskan:
a. kekeluargaan;
b. demokrasi ekonomi;
c. kebersamaan;
d. efisiensi berkeadilan;
e. berkelanjutan;
f. berwawasan lingkungan;
g. kemandirian;
h. keseimbangan kemajuan;
i. kesatuan ekonomi nasional

Adanya beberapa asas yang melekat kepada para UMKM maka diharapkan para pelaku UMKM memiliki rasa kekeluargaan, kebersamaan, dan kemandirian yang erat sehingga terjadi persaingan yang sehat sesama pelaku UMKM. 


\section{Permodalan UMKM}

Pengelolaan usaha ini dilakukan secara sederhana sehingga lebih banyak menjadi pilihan karena memerlukan modal yang relatif kecil. Namun beberapa kendala perlu dihadapai UMKM. Bagi usaha mikro dan kecil, sumber pembiayaan konvensional seperti perbankan dinilai memiliki syarat administrasi yang sulit dengan nilai pinjaman yang terbatas (BPS, 2019). Untuk mengembangkan usaha, UMK harus meningkatkan kapasitas produksi yang memerlukan modal tidak sedikit. Pengeluaran untuk usaha dan rumah tangga terkadang tercampur dan sulit dibedakan. Tercampurnya penggunaan kredit dalam pengelolaan usaha akan menjadi kendala bagi UMK untuk pengembangan (BPS, 2019).

Hasil Sensus Ekonomi 2016 Lanjutan diperoleh informasi bahwa mayoritas UMK mengeluarkan modal awal lebih dari separuhnya berasal dari dompet sendiri. Hal ini merata di semua jenis aktivitas usaha dengan persentase lebih dari 90 persen. UMK yang mengandalkan modal awal dari bank hanya mencapai 7 persen.

Alternatif lainnya pada permodalan UMKM yaitu Kredit Usaha Mikro (KUM) sebagai sumber pembiayaan selain KUR. Kredit ini diperuntukkan bagi UMK. Jika dilihat dari skala usahanya, pertumbuhan kredit UMKM usaha mikro paling tinggi di antara usaha kecil dan usaha menengah. Karakteristik usaha menjadi faktor yang dominan yang menentukan aksesibilitas permodalan. Selain itu track record atau karakter pengusaha, pendidikan yang akan meningkatkan kemampuan pengusaha dalam memahami prosedur kredit, dan kemitraan. Usaha berskala kecil tidak terlalu tergantung pada modal besar atau pinjaman dari luar dalam mata uang asing (Yuli, 2017).

\section{Metode Penelitian}

Jenis penelitian yang digunakan yaitu penelitian kepustakaan (library research). Penelitian ini menggunakan metode dengan pendekatan kualitatif yang menyajikan analisa bersifat deskriptif. Penelitian kepustakaan ini menyajikan data kepustakaan dengan mengumpulkan (synthesize), mengupas (criticize), dan meringkas (summarize) suatu literatur. Data dikumpulkan dengan cara studi dokumentasi dari berbagai literatur dan review laporan serta data sekunder yang berasal dari Ditjen Pajak, Bappenas, Badan Pusat Statistik (BPS), Kementrian Keuangan, Peraturan Pemerintah, Undang-Undang,

\section{Analisis Corak Pemikiran Hukum Teologi Asy'ariyyah}

\section{Rekomendasi Kebijakan UMKM}

Beberapa rekomendasi bagi kebijakan UMKM diantaranya berdasarkan poin di bawah ini:

a) SDM. Menurut BPS (2019), pelaku UMK yang mayoritas berpendidikan dan memiliki jiwa kewirausahaan yang rendah perlu diberikan pelatihan terkait motivasi usaha (jiwa kewirausahaan), kemampuan manajerial (pemasaran, produksi, SDM, keuangan), dan kemampuan aspek teknis (fashion, perbengkelan, budi daya pertanian, dan lainnya). Di samping itu perlu ada 
perubahan mindset UMK untuk mengembangkan usaha bukan hanya memenuhi kebutuhan keluarga saja.

b) Pendampingan. Pemerintah dapat membantu pengembangan UMK melalui pendampingan (BPS, 2019).

c) Regulasi. Pemerintah dapat membantu pengembangan UMK melalui penyusunan regulasi yang melindungi dan meningkatkan kinerja UMK. Regulasi terkait persoalan bagi kemudahan permodalan UMKM.

d) Penyediaan. Integrasi penyediaan modal sampai pengembangan UMKM harus menjadi prioritas, dengan demikian komoditas-komoditas Indonesia mampu bersaing pada tingkat domestik maupun global. Peningkatan penyediaan infrastruktur informasi.

Menurut Menurut Monitor Deloitte (Sumengkar, 2019) untuk menumbuhkembangkan kewirausahaan, empat hal yang harus diperhatikan oleh pemerintah yaitu:

a. Aset Kewirausahaan. Bagaimana pemerintah dapat mengatur agar UMKM bisa meningkatkan aset yang mereka miliki melalui akses ke pembiayaan, peningkatan kapabilitas atau keahlian serta penguatan infrastruktur pendukung, dan teknologi

b. Layanan Bisnis. Pemerintah dapat menyediakan layanan penunjang berupa program pendampingan, pengembangan bisnis dan komersialisasi teknologi.

c. Akselerasi Bisnis. Pemerintah membantu UMKM untuk mengakselerasi pertumbuhan bisnis melalui pemberian insentif pajak, menumbuhkan iklim persaingan yang sehat dan memotong biaya administrasi yang tidak perlu

d. Motivasi. Pemerintah merubah atau membentuk pola pikir yang positif tentang wirausaha.

\section{Kebijakan bagi UMKM}

Aspek-aspek kebijakan bagi UMKM berdasar Undang-Undang Nomor 20 Tahun 2008 meliputi:

1. Pendanaan;

Undang-Undang Republik Indonesia Nomor 20 Tahun 2008 Tentang Usaha Mikro, Kecil, dan Menengah memiliki beberapa point aturan yang berkaitan erat dengan implementasi Keuangan Berkelanjutan di Indonesia. Point aturan tersebut terdiri atas pasal-pasal berikut ini:

a) Bab II Asas dan Tujuan Pasal 2 mengatur bahwa Usaha Mikro, Kecil dan Menengah berasaskan berwawasan lingkungan. Yang dimaksud dengan "asas berwawasan lingkungan" adalah asas pemberdayaan Usaha Mikro, Kecil, dan Menengah yang dilakukan dengan tetap memperhatikan dan mengutamakan perlindungan dan pemeliharaan lingkungan hidup.

b) Bab VI Pasal 20 mengatur bahwa Pemerintah dan Pemerintah Daerah memfasilitasi pengembangan usaha dengan cara memberikan insentif 
bagi Usaha Mikro, Kecil dan Menengah mengembangkan teknologi dan kelestarian lingkungan hidup.

c) Bab VII Pembiayaan dan Penjaminan Pasal 22 menjelaskan bahwa dalam rangka meningkatkan sumber pembiayaan Usaha Mikro dan Usaha Kecil, Pemerintah melakukan upaya: Pengembangan sumber pembiayaan dari kredit perbankan dan lembaga keuangan bukan bank; Pengembangan lembaga modal ventura; Pelembagaan terhadap transaksi anjak piutang;

Upaya pemerintah melalui Kementerian Dalam Negeri pada bulan Juni 2016 mencabut atau merevisi 3.143 Peraturan Daerah dan Peraturan Kepala Daerah yang mayoritas menghambat investasi. Pemangkasan suku bunga Kredit Usaha Rakyat (KUR). suku bunga KUR diturunkan bertahap menjadi 12\%, 9\% dan kini hanya tinggal 7\% (Prasetyo, 2019).

Penurunan pajak UMKM. Pemerintah memangkas aturan Pajak Penghasilan (PPh) final bagi UMKM dari 1\% menjadi 0,5\%. Pemerintah menerbitkan kebijakan penurunan tarif Pajak Penghasilan (PPh) Final bagi UMKM dari 1\% menjadi 0,5\%. Aturan tersebut dituangkan dalam Peraturan Pemerintah (PP) Nomor 23 Tahun 2018 tentang Pajak Penghasilan atas

Penghasilan Dari Usaha yang Diterima atau Diperoleh Wajib Pajak yang Memiliki Peredaran Bruto Tertentu sebagai pengganti atas Peraturan Pemerintah Nomor 46 Tahun 2013, yang diberlakukan secara efektif per 1 Juli 2018 (Ditjen Pajak, 2018).

Adanya program pelatihan kewirausahaan dan bantuan modal usaha bagi wirausaha pemula yang nilainya maksimal Rp25 juta. bantuan atau kredit dana bergulir dari Lembaga Pengelola Dana Bergulir dari Kementerian Koperasi dan UKM serta Program Kemitraan dan Bina Lingkungan dan Program Pembiayaan melalui Tanggung Jawab Sosial Perusahaan (CSR), yang dananya berasal dari Badan Usaha Milik Negara, Badan Usaha Milik Daerah, dan Perusahaan Swasta (Permana,2015)

2. Sarana dan prasarana;

Mengadakan prasarana umum yang dapat mendorong dan mengembangkan pertumbuhan Usaha Mikro dan Kecil. Serta memberikan keringanan tarif prasarana tertentu bagi Usaha Mikro dan Kecil.

3. Informasi usaha

Membentuk dan mempermudah pemanfaatan bank data dan jaringan informasi bisnis serta mengadakan dan menyebarluaskan informasi mengenai pasar, sumber pembiayaan, komoditas, penjaminan, desain dan teknologi, dan mutu. Memberikan jaminan transparansi dan akses yang sama bagi semua pelaku Usaha Mikro, Kecil, dan Menengah atas segala informasi usaha. 
4. Kemitraan;

Mewujudkan kemitraan antar-Usaha Mikro, Kecil, dan Menengah, antara Usaha Mikro, Kecil, Menengah, dan Usaha Besar. Mendorong terjadinya hubungan yang saling menguntungkan dalam pelaksanaan transaksi usaha antar-Usaha Mikro, Kecil, dan Menengah, dan antara Usaha Mikro, Kecil, Menengah, dan Usaha Besar. Mengembangkan kerjasama untuk meningkatkan posisi tawar UMKM. Mendorong terbentuknya struktur pasar yang menjamin tumbuhnya persaingan usaha yang sehat dan melindungi konsumen. Mencegah terjadinya penguasaan pasar dan pemusatan usaha oleh orang perorangan atau kelompok tertentu yang merugikan UMKM.

Usaha menjamin kemajuan dan pengembangan UMKM diprogramkan oleh Departemen Keuangan melalui SK Menteri Keuangan (Menkeu) No.316/KMK.016/1994. SK tersebut mewajibkan Badan Usaha Milik Negara (BUMN) untuk menyisihkan 1-5\% laba perusahaan bagi Pembinaan Usaha Kecil dan Koperasi (PUKK).

5. Perizinan usaha;

Menyederhanakan tata cara dan jenis perizinan usaha dengan sistem pelayanan terpadu satu pintu dan membebaskan biaya perizinan bagi Usaha Mikro dan memberikan keringanan biaya perizinan bagi Usaha Kecil. Penerapan Online Single Submission (OSS) sehingga proses perizinan untuk berusaha lebih cepat (Paskalia, 2019).

6. Kesempatan berusaha;

Menentukan peruntukan tempat usaha (pemberian lokasi di pasar, ruang pertokoan, lokasi sentra industri, lokasi pertanian dan pertambangan rakyat, lokasi yang wajar bagi pedagang kaki lima, serta lokasi lainnya. Menetapkan alokasi waktu berusaha untuk UMK. Mencadangkan bidang dan jenis kegiatan usaha yang memiliki kekhususan proses, bersifat padat karya, serta mempunyai warisan budaya. Menetapkan bidang usaha yang dicadangkan untuk UMKM serta bidang usaha yang terbuka untuk Usaha Besar dengan syarat harus bekerja sama dengan UMKM. Melindungi usaha tertentu yang strategis untuk UMKM. Mengutamakan penggunaan produk yang dihasilkan oleh UMK melalui pengadaan secara langsung. Memprioritaskan pengadaan barang atau jasa dan pemborongan kerja Pemerintah dan Pemerintah Daerah. Memberikan bantuan konsultasi hukum dan pembelaan.

Dukungan lainnya yaitu dari Kementerian Badan Usaha Milik Negara (BUMN) lewat PKBL atau Program Kemitraan dan Bina Lingkungan. PKBL merupakan Program Pembinaan Usaha Kecil dan pemberdayaan kondisi lingkungan oleh BUMN melalui pemanfaatan dana dari bagian laba BUMN (Paskalia, 2019). 
7. Promosi dagang;

Meningkatkan promosi produk UMKM di dalam dan luar negeri. Memperluas sumber pendanaan untuk promosi. Memberikan insentif dan tata cara pemberian insentif untuk UMKM yang mampu menyediakan pendanaan secara mandiri dalam kegiatan promosi produk di dalam dan luar negeri. Memfasilitasi pemilikan hak atas kekayaan intelektual atas produk dan desain UMKM dalam kegiatan usaha dalam negeri dan ekspor. Pemberian bantuan pemasaran dan pelatihan. Menyelenggarakan berbagai edukasi kepada para pelaku UKM ataupun masyarakat yang hendak terkun ke sektor UMKM.

Dilakukan pelatihan operasional pemasaran online dan listing penjualan produk di situs e-commerce. Dalam setiap pengelolaan RKB BUMN, UMKM akan melalui tiga tahap mulai dari Go Modern, Go Digital, dan Go Online. Go Modern dimulai dari bimbingan registrasi di situs www.rkb.id, standarisasi produk, serta pelatihan pengelolaan branding. Pemerintah memiliki program gerakan 100.000 UMKM Go Online secara serentak di 30 kota/kabupaten di Indonesia digagas seiring dengan visi pemerintah untuk menjadikan Indonesia sebagai Digital Energy of Asia. Dalam hal ini Kementerian KUKM bersama Kementerian Kominfo berkomitmen untuk mengonlinekan 8 Juta UMKM sampai tahun 2020 (Paskalia, 2019).

8. Dukungan kelembagaan.

Mengembangkan dan meningkatkan fungsi inkubator, lembaga layanan pengembangan usaha, konsultan keuangan mitra bank, dan lembaga profesi sejenis lainnya sebagai lembaga pendukung pengembangan UMKM. Peraturan Pemerintah RI Nomor 17 Tahun 2013, yang menyatakan bahwa pengembangan Usaha Mikro, Usaha Kecil, dan Usaha Menengah dilakukan melalui pendataan, identifikasi potensi, dan masalah yang dihadapi.

Membentuk Penyelenggaraan Pelayanan Terpadu Satu Pintu (PTSP) melalui Peraturan Presiden (Perpres) Nomor 97 Tahun 2014, yang kemudian juga diikuti oleh pemerintahan daerah. Hingga saat ini telah terbentuk 511 PTSP di seluruh Indonesia atau 90 persen daerah telah memiliki PTSP.

\section{E. Simpulan}

Kebijakan peningkatan pelaku usaha mikro, kecil, dan menengah telah dilakukan pemerintah berdasarkan Undang-Undang Nomor 20 Tahun 2008 yang diupayakan melalui Peraturan Presiden, Peraturan Pemerintah Republik Indonesia Nomor 17 Tahun 2013, dan Peraturan Pemerintah Daerah untuk meningkatkan kualitas dan kuantitas UMKM. Beberapa aspek menjadi sangat penting bagi peningkatan UMKM diantaranya aspek pendanaan, sarana dan prasaraan, kemitraan, perizinan, promosi, dan dukungan kelembagaan. Pemerintah telah menerbitkan kebijakan-kebijakan sebagai solusi atas 
permasalahan UMKM. Kebijakan yang telah ditetapkan dalam rangka meningkatkan kualitas maupun kuantitas para pelaku UMKM di Indonesia.

\section{DAFTAR PUSTAKA}

Bappenas. 2014. Rencana Pembangunan Jangka Menengah Nasional 2015-2019 Buku I Agenda Pembangunan Nasional. Jakarta: Bappenas.

BPS. 2019. Potensi Peningkatan Kinerja Usaha Mikro Kecil, Analisis Hasil SE2016 Lanjutan. BPS Indonesia.

Ditjen Pajak. 2018. Pemerintah Turunkan Tarif PPh Final UMKM jadi 0,5 Persen. Diakses dari https://www.pajak.go.id Tanggal 29 Januari 2020.

Islamiyati, Nelsi. 2017. 5 Permasalahan Utama yang Dibadapi Para Pelaku UMKM. Diakses dari https://www.jagoanhosting.com Tanggal 29 Januari 2020.

Kementrian Keuangan. 2018. Ini Bentuk Perbatian Pemerintah terhadap UMKM. Diakses dari https://www.kemenkeu.go.id Tanggal 29 Januari 2020.

Keputusan Presiden Republik Indonesia Nomor 14 Tahun 2015 Tentang Komite Kebijakan Pembiayaan Bagi Usaha Mikro, Kecil, Dan Menengah.

LPPI dan BI. 2015. Profil Bisnis Usaha Mikro, Kecil Dan Menengah (Umkm) Kerjasama Lppi Dengan Bank Indonesia Tabun 2015.

Meryana, Ester. 2012. Dampak Kenaikan Harga BBM pada sektor UKM di Indonesia. Diakses dari https://megapolitan.kompas.com Tanggal 29 Januari 2020.

Paskalia. 2019. 4 Regulasi UKM Ini Perlu Kamu Ketabui Sebelum Memulai Usaha. Diakses dari https://www.modalrakyat.id Tanggal 29 Januari 2019.

Peraturan Pemerintah Republik Indonesia Nomor 17 Tahun 2013 Tentang Pelaksanaan Undang-Undang Nomor 20 Tahun 2008 Tentang Usaha Mikro, Kecil, Dan Menengah.

Permana, Sony Hendra. 2017. Strategi Peningkatan Usaba Mikro, Kecil, Dan Menengah (Umkm) Di Indonesia. Diakses dari http://www.jurnal.dpr.go.id Tanggal 29 Januari 2020.

Prasetyantoko. 2019. Mimpi Indonesia menjadi Negara Ekonomi Besar. Diakses dari https://katadata.co.id. Tanggal 29 Januari 2020.

Prasetyo, Andhika. 2019. Kebijakan Pemerintah Bukti Keberpibakan kepada UKM. Diakses dari https://mediaindonesia.com Tanggal 29 Januari 2020.

Putra, Langgeng R., dkk. 2018. Strategi Pengembangan Usaba Mikro, Kecil Dan Menengah (Umkm) Ekonomi Kreatif Kerajinan Kulit Di Kabupaten Magetan (Studi Pada Dinas Perindustrian Dan Perdagangan Kabupaten Magetan). Surabaya: Jurnal Untag.

Saefudin, A. 2016. Analisis Pengaruh Kualitas Produk, Harga Produk, dan Orientasi Pasar terhadap Kinerja Penjualan pada UMKM Pengrajin Kayu di Gilingan Kota Surakarta. Diakses dari http://www.eprints.ums.ac.id Tanggal 29 Januari 2020.

Suci, Yuli Rahmini. 2017. Perkembangan Umkm (Usaha Mikro Kecil Dan Menengah) Di Indonesia. Balikpapan: Jurnal Ilmiah Cano Ekonomos. 
Sumengkar, Apung. 2019. Peranan Pemerintah untuk Mengembangkan UMKM di Indonesia. Diakses dari https:/ / fmbpartner.com Tanggal 29 Januari 2020.

Suryanto, dkk. 2017. Profile and Problem of Micro, Small and Medium Enterprises in Bandung. Advances in Social Science, Education and Humanities Research (ASSEHR), volume 141.

Tambunan, Tulus. 2012. Usaha Mikro, Kecil dan Menengab di Indonesia. Isu-isu Penting. Jakarta: LP3ES.

Tempo.co. 2016. Pemerintah Pusat Gencar Deregulasi, Daerah Belum Ikuti. Diakses dari https://bisnis.tempo.co Tanggal 29 Januari 2020.

Tunggal, Amin Widjaja. (2008). Corporate Social Responsibility (CSR). Jakarta: Harvarindo. Undang-Undang RI No. 20 Tahun 2008 Tentang Usaha Mikro, Kecil, Dan Menengah. 